\begin{tabular}{|l|l|l|}
\hline \multicolumn{2}{|c|}{ PublisherInfo } \\
\hline \hline PublisherName & $:$ & BioMed Central \\
\hline \hline PublisherLocation & $:$ & London \\
\hline \hline PublisherImprintName & $:$ & BioMed Central \\
\hline \hline
\end{tabular}

\title{
Tumor suppression by FEZ
}

\begin{tabular}{|l|l|l||}
\hline \multicolumn{2}{|c|}{ ArticleInfo } \\
\hline \hline ArticleID & $:$ & 4182 \\
\hline \hline ArticleDOI & $:$ & $10.1186 /$ gb-spotlight-20010821-01 \\
\hline \hline ArticleCitationID & $:$ & spotlight-20010821-01 \\
\hline \hline ArticleSequenceNumber & $:$ & 253 \\
\hline \hline ArticleCategory & $:$ & Research news \\
\hline \hline ArticleFirstPage & $:$ & 1 \\
\hline \hline ArticleLastPage & $:$ & 2 \\
\hline \hline & & RegistrationDate : 2001-08-21 \\
ArticleHistory & $:$ & OnlineDate $\quad$ 2001-08-21 \\
\hline \hline ArticleCopyright & $:$ & BioMed Central Ltd2001 \\
\hline \hline ArticleGrants & $:$ & \\
\hline \hline ArticleContext & $:$ & 130592211 \\
\hline \hline
\end{tabular}




\section{Jonathan B Weitzman}

Email: jonathanweitzman@hotmail.com

The FEZ1/LZTS1 gene maps to chromosome 8p22, a region lost in many tumors. In the Early Edition of the Proceedings of the National Academy of Sciences, Hideshi Ishii and colleagues, from Thomas Jefferson University, Philadelphia, describe a mechanism for FEZ1-mediated growth suppression. They created an inducible gene-expression system in MCF7 breast cancer cells, in which FEZ1 expression was controlled by tetracycline. FEZ1 expression inhibited cell growth in vitro (at the S-phase to G2/M transition in the cell cycle) and tumor formation in vivo. Ishii et al.demonstrated that the FEZ1 protein is phosphorylated by cAMP-dependent protein kinase (PKA) during the cell cycle. Two-hybrid proteinprotein interaction analysis in yeast showed that FEZ1 interacts with elongation factor EF1 $\gamma$. Also, FEZ1 is associated with microtubule components and with the p34cdc2 mitotic kinase. FEZ1 appears to suppress tumor growth by regulating microtubule dynamics and progression through mitosis.

\section{References}

1. The FEZ1 gene at chromosome $8 \mathrm{p} 22$ encodes a leucine-zipper protein, and its expression is altered in multiple human tumors.

2. Proceedings of the National Academy of Sciences, [http://www.pnas.org]

3. Thomas Jefferson University, [http://www.tju.edu]

4. FEZ1/LZTS1 gene at $8 \mathrm{p} 22$ suppresses cancer cell growth and regulates mitosis., [http://www.pnas.org/cgi/content/abstract/181222898v1] 